typical fossil of the intertrappean beds of the Deccan, named in honour of the well-known secretary of the Asiatic Society of Bengal, James Prinsep. Numerous photographic views, diagrams, and maps add to the interest of the work, most of which are taken with due acknowledgment from the publications of the Geological Survey of India. Of the author's own views, two have been selected for reproduction, one showing a typical landscape in the crystalline area of the peninsula, and the other that unique feature in one of the great peninsular rivers - the falls on the Narbada, near Jabalpur.

T. H. D. L.

\section{METEOROLOGY IN THREE DIMENSIONS 1}

I $1916 \mathrm{Mr}$. W. H. Dines put together in a concise report the information then available about the pressure, temperature, and density of the atmosphere up to heights of $15-20$ kilometres. His report is now published, and shouid prove extremely useful and informing both to the new generation of meteorologists and to the wider circle whose interest in the atmosphere is nonprofessional.

The first nine sections deal with the methods and places of observation, the averages and seasonal variations of pressure, temperature, and density, and the stratosphere and troposphere; short accounts of humidity and atmospheric motion are also included.

The tenth and eleventh sections are concerned with the results of the statistical treatment of the original data; the interpretation of these results will provoke much discussion. First, the correlation coefficient between ( $I$ ) the mean temperature of a vertical column extending from a height of $\mathrm{x} \mathrm{km}$. to a height of $9 \mathrm{~km}$. and (2) the pressure at the top of the column is 0.95 . The hydrostatic equation connecting variations of pressure at $\mathrm{I} \mathrm{km}$. and $9 \mathrm{~km}$. with variations of the mean temperature of the column of air is

$$
\frac{\delta p_{9}}{p_{9}}=\frac{\delta p_{1}}{p_{1}}+\frac{k \delta \mathrm{T}}{\mathrm{T}^{2}}
$$

From this it follows that if $\frac{\delta p_{1}}{p_{1}}$ is (r) zero or (2) proportional to $\frac{\delta p_{9}}{p_{9}}$, then the correlation coefficient between $p_{9}$ and $T$ is unity.

The first condition is not fulfilled in temperate latitudes; the second condition would be satisfied if the isobars at $9 \mathrm{~km}$. were parallel to those at r $\mathrm{km}$.-i.c. if the wind-directions at these levels were identical. But in the troposphere convection is always tending to make the direction of the wind the same at all levels, so that the magnitude of the correlation coefficient found by $\mathrm{Mr}$. Dines may be due to the effectiveness of convection in regulating the wind. It would be interesting to know the differences from parallelism

1 Meteorological Office. Ceophysical Memoirs, No. 13. "The Characteristics of the Free Atmosphere." (London: Meteorological Office, Igrg.) Price 25, net.

$$
\text { NO. } 2620, \text { VOL. IO4] }
$$

permitted by the 0.05 by which the actual coefficient falls short of unity.

Secondly, if $T_{0}, P_{0} ; T_{1}, P_{1}$, etc., are the temperatures and pressures at heights of $0, \mathbf{I}, 2$, . I 3 kilometres, then the correlation coefficients between corresponding T's and P's, beginning with $\mathrm{T}_{0}, \mathrm{P}_{0}$, are as follows : . I 1 , .42,.66,.77,.84, $.85, .86, .86, .86, .71, .32,-.19,-.36,-.28$. It follows that pressure and temperature go up and down together with great regularity at all heights between $3 \mathrm{~km}$. and $9 \mathrm{~km}$. Presumably the same would hold for the surface were it not for the effects of radiation and of the surface water of the ocean upon the surface temperature of the air.

Two outstanding deficiencies in the information available call for comment. There are no records from the United States, India, Australia, South Africa, South America, and Japan. This is no doubt partly due to the difficulties of recovering records in these countries if the ordinary European method of investigation is used; but it is also due to the defects of pre-war international meteorological organisation in which no place was found for an active permanent bureau. Further, the information about atmospheric motion is hopelessly inadequate. This arises less from lack of original records than from the absence of any proper arrangements for summarising the results of pilotballoon ascents. A young meteorologist seeking a field of independent research might do worse than turn to the statistical treatment of vectors.

Before the war the investigation of the free atmosphere was, broadly speaking, pure research; the work had no direct application in forecasting or climatology, and the means of investigation were slight and relatively expensive. During the war a knowledge of the actual conditions of the atmosphere at least up to $20,000 \mathrm{ft}$. $(6 \mathrm{~km}$.) became essential for heavy artillery and for aviation, and their importance for actual daily forccasting began to be dimly recognised. Now that artillery operations are over and aviation is practically restricted to low levels, there is a great risk of the investigation at higher levels by aeroplanes and kiteballoons being neglected; and instead of information being available an hour or two after it was obtained, records would again creep in months or years out of date, with no possibility of immediate practical usefulness. E. GOLD.

\section{SIR THOMAS R. FRASER, F.R.S.}

$W^{H E N}$, in 1877 , and then in his thirty-sixth year, Thomas Richard Fraser was called to succeed Sir Robert Christison as professor of materia medica in Edinburgh University, it could scarcely have been anticipated how closely he was to rival his great master in his length of tenure of the chair and in the distinction with which he :vas to fill it. In his varied spheres of action Fraser attained a commanding position as a physician, as an investigator, and as a professor.

Gifted with acute senses and a fearlessly logical mind, and trained in the habits of accurate obI servation and experiment in the laboratory, Fraser 
brought to the hospital wards a rare combination of qualities. He had few equals as a diagnostician and therapeutist. As a teacher, his unswerving scientific attitude to the problems of clinical medicine had on the thousands of students who passed through his hands an influence scarcely to be overestimated. He taught not only accuracy of method, but also precision of language. His gifts as a physician were recognised by his holding, among other distinctions, the offices of physician to the King in Scotland, and of president of the College of Physicians of Edinburgh, of the Association of Physicians of Great Britain and Ireland, and of the Indian Plague Commission. He was knighted in 1902.

As an investigator, Fraser was one of the pioneers of experimental pharmacology. His greatest discoveries -from the point of view of their immediate practical application--were those which, in strophanthus and physostigmine, added to our Pharmacopœia remedies still in everyday use for the purposes for which he recommended them. For far-reaching scientific value they were even exceeded by the monograph which he wrote in collaboration with Prof. Crum Brown on the relation between chemical constitution and physiological action, embodying one of the most suggestive and fruitful researches in the history of pharmacology. For his researches he was made a laureate and Barbier prizeman of the French Academy of Sciences, and was awarded the Macdougall Brisbane and Keith prizes of the Royal Society of Edinburgh.

Fraser combined an aptitude for both science and business. He took a keen interest in educational problems and an active part in introducing many university reforms. For twenty years he acted as dean of the faculty of meticine, and for ten years represented that faculty on the University court, and his University on the General Medical Council.

Endowed with a remarkably lucid and quick minc: himself, Fraser was intolerant of mental slowness in others, sparing of praise, and at times not slow to censure. But he expected a man's best, and his standard was high. He carried himself - a keen, spare, scholarly figure-with a faint, indefinable hauteur, which may have been to many a barrier to close intimacy. But when this barrier was surmounted, and when he could lay aside the cares of too unremitting labour and of indifferent health, he would weave a grace and charm which few could resist or forget. Especially in later years he fought a continual battle with bronchitis and emphysema with a fortitude which is surely characteristic of sufferers from this condition. That he was so long permitted to lead an active life-for he retired only two years ago-was due in no small measure to the loving care and encouragement of Lady Fraser and the kindly supervision of his staunch friend and physician, Sir James Affleck.

Plummer, Gregory, Fowler, Withering, Lister, Simpson, Hughes Bennett, Christison, Brunton, Fraser-alumni or professors of the University of Edinburgh, a roll enviable and for one medical NO. 2620 , VOL. IO4] school possibly unequalled-file before us in retrospect. Their achievements in adding to our knowledge of remedies for disease and for pain stretch from the picturesque twilight of empiricism to the clear light of scientific method. With the passage of the last to that unknown bourn, we salute their memory. J. A. G.

\section{NOTES}

A SPECIAL general meeting of the Royal Society will be held on January 22 , at 3.30 , to admit H.R.H. the Prince of Wales as a fellow of the society.

THE meeting of February 5 has been set apart by the council of the Royal Society as a meeting for a discussion on "The Theory of Relativity," to be opened by Mr. Jeans and continued by Prof. Eddington, the Astronomer Royal, and others.

THE International Research Council has been constituted, by successive meetings in London, Paris, and Brussels, as a Federation of National Research Unions. Under its auspices unions are being formed for the organisation of international work and co-operation in different departments of science, the unions already instituted being for astronomy, geodesy and geophysics, mathematics, and (provisionally) chemistry and biology. The question of international organisation in science is raised, to a great extent, by Article 282 of the Peace Treaty, which states that "treaties, conventions, and agreements of an economic and technical character not included in a specified list cease to be operative." That this article was intended to cover conventions on scientific matters appears from the list of exceptions, in which the Metric Convention and the International Agricultural Institute at Rome are included.

With the view of obtaining the opinion of representatives of pure and applied science upon the subject of the co-ordination of international effort and action, a special meeting of the Conjoint Board of Scientific Societies was held at the Royal Society on January 8. After much discussion the following resolutions were passed:"(I) That the executive committee be requested to appoint committees for the purpose of considering the desirability of forming in branches of science, as recommended by the Brussels Conference, international unions connected with the International Research Council, or of joining such Unions if formed independently. (2) That these committees be authorised to make recommendations with regard to the proposed statutes and the constitution of national research councils. (3) That the committees consist of representatives nominated by the principal societies concerned, together with additional members nominated by the executive committee."

WE regret to see the announcement of the death on January II, at seventy-three years of age, of Father J. N. Strassmaier, the distinguished Assyriologist, whose work with Father Epping on Assyrian astronomy is well known.

THE Scientific Instrument, Glassware, and Potash Production Section of the Board of Trade has been transferred from 7 Seamore Place, W.I, to the main offices at Great George Street, S.W.I. 